Religiosity: Development of religious cognitive schemas and religious faith

Proios, Miltiadis $\bowtie$

Aristotle University, Greece (mproios@phed.auth.gr)

Dianni, Maria

Greece (mdianni@hotmail.com)

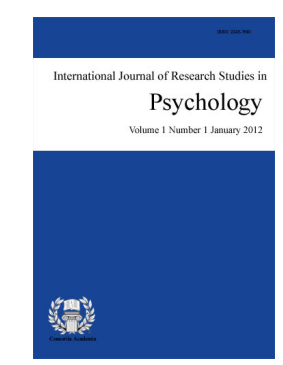

Samara, Eleni

ISSN: 2243-7681

Greece( Samara_eleni@yahoo.com

Syropoulos, Dimitrios

OPEN ACCESS

Greece (syropoulos@sch.gr)

\title{
Abstract
}

The goal of the present study was to investigate developmental changes in the religiosity of individuals in relation to age, education and gender. The study also investigated the relation among religious faith and religious schemas. The sample used was comprised of 285 individuals of Christian Orthodox faith (men $n=128$, women $n=157$ ) with ages range of 13-86 years $(\mathrm{M}=26.69, \mathrm{SD}=15.80)$. Participants had high school, lyceum, graduate, and post graduate education. All participants filled out two questionnaires, Santa Clara Strength of Religious Faith Questionnaire and Religious Schema Scale. Results showed a significant affect mostly of age and education and less of gender on the formation of religiosity. Results also presented a significant relation among religious faith and religious schemas of truth of texts and teachings (ttt) and fairness, tolerance and rational choice (frt).

Keywords: religiosity; religious schemas; religious faith; orthodox Christian 


\section{Religiosity: Development of religious cognitive schemas and religious faith}

\section{Introduction}

The term religiosity is part of the field of psychology of religion (Paloutzian \& Park, 2005). The interest for the studying of religiosity has mostly risen throughout the last two decades (King \& Crowther, 2004), creating a wide range of definitions not always clear (Hill, Pargament, Hood, et al., 2000; Zinnbauer, Pargament, \& Cowell, 1997). Fetzer Institute (1999), Hackney and Sanders (2003) stated that religiosity is a difficult term to define but Peterman, Fitchett, Brady, Hernandez, and Cella (2002) have defined religiosity as society-based beliefs and practices relating to a higher power commonly associated with a church or organized group.

Religiosity within the area of developmental science continues to be considered as a rather rare topic to inquire (King \& Roeser, 2009). The domain of religious development is intensely affected by the views of Piaget on the psychology of human development. This could be seen by the interest shown in the past by researchers for the study of the development of religious faith (e.g., Fowler, 1981, 1987, 1996; Fowler \& Dell, 2005; Gibson, 2004; Oser \& Grunder, 1991; Oser \& Reich, 1996). According to Fowler religious, spiritual growth is a continuous procedure which includes a number of stages (six-stage model) (Fowler, 1981). Nevertheless, Fowler's view that faith development can be viewed as a "hard stage" model has been heavily criticized (see, e.g., Boyatzis, 2005; Day, 2010; Streib, 2001, 2010). Research has indicated that children and adults may not be altogether different in their thinking (see, e.g., Boyatzis, 2005).

Considering the aforementioned criticism on hard stage theory, Streib (2001) moved to revise Fowler's faith development theory. He suggested religious schemata which are the distinguishing marks for religious styles. Religious styles resemble-and relate to-lifestyles and habits (Bourdieu, 1979). The following schemas were considered as of central importance in religious or faith development: truth of text and teachings (ttt), fairness, tolerance and rational choice (ftr) and xenosophia, inter-religious dialog (xenos) (Streib, Hood, \& Klein, 2010).

The developmental characteristic of religiosity is an issue not of special interest in the field of developmental science (King \& Roser, 2009). Keller and Streib (2013) supported that in religious development research no longitudinal study exists. In developmental sciences age is considered as a developmental indicator. Research on age-related differences in indicators of religious attendance and salience is equivocal. Findings showed that only two-thirds of adolescents presented continuous levels of religious importance from the middle to high school years while the rest of the sample showed a discontinuity during this period with attitudes changing from both favorable to unfavorable and vice versa (Benson, Scales, Sesma, \& Roehlkertain, 2005). Findings of other studies revealed less attendance among older adolescents (Wallace, Forman, Caldwell, \& Willis, 2003), and minor age-related differences in various indicators of religiosity in the cross-sectional, national study of 13-17 year olds (Smith \& Denton, 2005).

According to cognitive-developmental theory, apart from age, education is an important factor for cognitive development. Cognitive development has been proved to be linked to spiritual growth (Sinnott, 1994). Spiritual growth is development or improvement toward perfection, while Glory of God is considered as the supreme principle for the achievement of spiritual development (Gibson, 2004).

Gender is a variable where religiosity seems to show differences within teenagers (Smith \& Denton 2005; Wallace et al. 2003), and adults (Batson, Schoenrade, \& Ventis, 1993; Beit-Hallahmi \& Argyle, 1997; Donahue \& Benson, 1995). Argyle and Beir-Hallahmi (1975) report that differences between men and women in their religious behavior and beliefs are considerable.

The importance of the present study lies upon the studying of the developmental course of aspects of religiosity, offering additional information on the understanding of religiosity by people. The basic goal of the 
present study is to investigate the developmental course of religious faith and religious schemas among people sharing the same orthodox Christian faith and various differences related to gender. The study also will attempt to examine the relation among the terms of religious faith and religious schemas. The present study supported that religious faith and religious schemas will show developmental characteristics in relation to age and education. It was also hypothesized that there should be a difference on religious faith and religious schemas relating to gender. Finally, it was hypothesized that there is a relation among religious faith and religious schemas.

\section{Method}

\subsection{Participants}

Participants were 285 Christians Orthodox (men $n=128$, and women $n=157$ ). Their age ranged from 13 to 86 years $(M=26.69, S D=15.80)$. For the sake of the study the sample was divided in seven age groups: (1) early adolescence 13-15 years, $n=66$, (2) adolescence 16-18 years, $n=41$, (3) late adolescence 19-24 years, $n=$ 80 , (4) young adult 25-30 years, $n=12$, (5) early adult 31-40 years, $n=22$, (6) middle adult 41-60 years, $n=48$, (7) late adult \& old age 61 years and older, $n=16$. Participants' education background was as follows: high school $(n=76)$, lyceum $(n=113)$, graduate $(n=82)$, post graduate $(n=14)$.

\subsection{Procedures}

The sample used in this study lived in a city with a population of one million. Questionnaires were filled in the absence of researchers. Specifically, the participants were members of several organizations (religious and social) and the questionnaires reached them through other members of these organizations.

\subsection{Measures}

Santa Clara Strength of Religious Faith Questionnaire: A validated Greek version (Dianni, Proios, \& Kouthouris, 2014) of the Santa Clara Strength of Religious Faith Questionnaire (SCSRFQ; Plante \& Boccaccini, $1997 \mathrm{a}, \mathrm{b})$ was used in order to assess religiosity. SCSRFQ is a 10-item self-report measure. The SCSRFQ uses a 4-point Likert response format, ranging from (1) Strongly disagree to (4) Strongly agree. The SCSRFQ was found to have high internal reliability, with Cronbach's alphas ranging between .94 and .97 and split-half reliability correlations between .90 and .96 . In the present study, the alpha coefficient was $(\alpha=.95)$.

Religious Schema Scale: A validated Greek version (Proios 2015) of the Religious Schema Scale (RSS; Streib et al. 2010) was used in order to assess religious development. RSS consists of three subscales of 5 items each. The RSS uses a 5-point Likert-type format from strongly agree to strongly disagree. Reliabilities of the three subscales in the current sample are: $\alpha=.88$ for the subscale truth of texts \& teachings (ttt), $\alpha=.65$ for fairness, tolerance \& rational choice ( $f t r)$ and $\alpha=.70$ for xenosophia \& inter-religious dialog (xenos).

\section{Results}

\subsection{Developmental changes on religious faith over time}

Descriptive statistics (Table 1) initially shows the strength of religious faith of the participants is relatively strong $(M=2.79, S D=.67)$, while within age groups analysis showed that age group of 61 and older presented higher scores $(M=3.28, S D=.38)$. By examining scores of each age group one sees that the strength of religious faith gradually decreases from the age of 13 to 24 . Scores also show that among ages of 25 to 40 there is an upward trend while ages 41-60 show a tendency for stagnancy. Finally, on ages 61 and above scores show an upward trend on the strength of religious faith. 
Proios, M., Dianni, M., Samara, E., \& Syropoulos, D.

A univariate analysis of variance (ANOVA) was computed to identify any age differences on religious faith. Analysis showed that religious faith varies according to age $\left(F(1,280)=6.38, p<.001, n^{2}=.12\right)$. According to Cohen (1988), guidelines for interpreting an eta square value $\left(\eta^{2}\right)$ is that .01 indicates a small effect, .09 indicates a moderate effect, and .25 indicates a large effect. Therefore, our finding $\eta^{2}=.12$ indicates that $12 \%$ of the total variance in variables of religious faith are accounted for by age differences and as such can be classified as a large effect.

Table 1

Descriptive Statistics

\begin{tabular}{|c|c|c|c|c|c|c|c|c|c|}
\hline \multirow[t]{2}{*}{ Groups age } & \multirow[t]{2}{*}{$\mathrm{N}$} & \multicolumn{2}{|c|}{ Religious faith } & \multicolumn{6}{|c|}{$\begin{array}{c}\text { Religious schema } \\
\mathrm{ftr}\end{array}$} \\
\hline & & $\mathrm{M}$ & SD & $\mathrm{M}$ & SD & $\mathrm{M}$ & SD & $\mathrm{M}$ & SD \\
\hline $13-15$ & 66 & 3.04 & .54 & 3.68 & .77 & 4.05 & .57 & 3.38 & .68 \\
\hline $16-18$ & 41 & 2.59 & .61 & 2.83 & .63 & 3.93 & .86 & 3.03 & .65 \\
\hline $19-24$ & 80 & 2.51 & .58 & 2.82 & .72 & 4.15 & .65 & 3.18 & .72 \\
\hline $25-30$ & 12 & 2.70 & .57 & 3.12 & 1.03 & 4.33 & .53 & 3.63 & .79 \\
\hline $31-40$ & 22 & 2.89 & .81 & 3.15 & 1.03 & 4.32 & .46 & 3.06 & .91 \\
\hline $41-60$ & 48 & 2.87 & .84 & 3.46 & .95 & 4.35 & .50 & 2.96 & .77 \\
\hline $61-86$ & 16 & 3.28 & .38 & 4.05 & .59 & 4.23 & .37 & 2.65 & .96 \\
\hline Total & 285 & 2.79 & .67 & 3.24 & .91 & 4.15 & .62 & 3.15 & .77 \\
\hline \multicolumn{2}{|c|}{ Differences (Sig.) } & \multicolumn{2}{|c|}{$\begin{array}{l}\text { (1)-(2) } \mathrm{M}=.45, p<.01 \\
\text { (1)-(3) } \mathrm{M}=.52, p<.001 \\
\text { (6)-(3) } \mathrm{M}=.36, p<.05 \\
\text { (7)-(2) } \mathrm{M}=.69, p, .01 \\
\text { (7)-(3) } \mathrm{M}=.76, p<.001\end{array}$} & $\begin{array}{l}\text { (1)-(2) M } \\
\text { (1)-(3) M } \\
\text { (6)-(2) M } \\
\text { (6)-(3) M } \\
\text { (7)-(2) M } \\
\text { (7)-(3) M } \\
\text { (7)-(4) M } \\
\text { (7)-(6) M }\end{array}$ & $\begin{array}{l}<<.001 \\
<.001 \\
<.01 \\
<.001 \\
p<.001 \\
p<.001 \\
<<.05 \\
<.05\end{array}$ & \multicolumn{2}{|c|}{ (6)-(2) $\mathrm{M}=.43, p<.05$} & \multicolumn{2}{|c|}{$\begin{array}{l}\text { (1)-(6) } \mathrm{M}=.42, p<.05 \\
\text { (1)-(7) } \mathrm{M}=.73, p<.01 \\
\text { (4)-(7) } \mathrm{M}=.98, p<.05\end{array}$} \\
\hline
\end{tabular}

A subsequent Tukey test for unequal values among age groups followed (Stevens 1996). Results indicated a predominance of age group 13-15 against age groups 16-18 and 19-24 $(\mathrm{t}=.45, p<.01$ and $\mathrm{t}=.52, p<.001$, respectively). The group age 61 and above presents a predominance against age groups $16-18$ and 19-24 $(\mathrm{t}=.69$, $p<.01$ and $\mathrm{t}=.76, p<.001$, respectively). Finally, age group 41-60 predominates over age group 19-24 $(\mathrm{t}=.36$, $p<.05)$.

\subsection{Developmental changes in religious faith in relation to education}

By observing the results of descriptive statistics (see Table 2) we see a dominance of the scores of religious faith by people of high school education $(M=3.11, S D=.54)$. Scores show a downward trend as the level of education gets higher and specifically up to graduate level of education. On the contrary on the post graduate level there is an increase of the scores of religious faith.

Table 2

Descriptive statistics

\begin{tabular}{|c|c|c|c|c|c|c|c|c|c|}
\hline \multirow[t]{2}{*}{ Levels education } & \multirow[t]{2}{*}{$\mathrm{N}$} & \multicolumn{2}{|c|}{ Religious faith } & \multicolumn{6}{|c|}{ Religious schema } \\
\hline & & $\mathrm{M}$ & SD & $\mathrm{M}$ & SD & $\mathrm{M}$ & SD & $\mathrm{M}$ & SD \\
\hline (1) Junior High school & 75 & 3.11 & .54 & 3.79 & .77 & 4.08 & .55 & 3.21 & .81 \\
\hline (2) Senior High School & 111 & 2.69 & .60 & 3.06 & .82 & 4.15 & .68 & 3.16 & .72 \\
\hline (3) University & 80 & 2.63 & .74 & 2.95 & .89 & 4.20 & .61 & 3.04 & .77 \\
\hline (4) Postgraduate & 14 & 2.74 & .95 & 3.34 & 1.11 & 4.31 & .63 & 3.33 & .85 \\
\hline Differences (Sig.) & & $\begin{array}{l}(1)-(2) \mathrm{M} \\
(1)-(3) \mathrm{M}\end{array}$ & $\begin{array}{l}p<.001 \\
p<.001\end{array}$ & $\begin{array}{l}\text { (1)-(2) M } \\
\text { (1)-(3) M }\end{array}$ & $\begin{array}{l}p<.001 \\
p<.001\end{array}$ & $p>.05$ & & $p>.05$ & \\
\hline
\end{tabular}

A univariate analysis of variance (ANOVA) was performed to identify any level education differences on religious faith. The analysis showed that the religious faith varies in relation to the level of education $(F(1,280)$ 
$\left.=8.66, p<.001, n^{2}=.09\right)$. The finding that $\eta^{2}=.09$ indicates that $9 \%$ of the total variance in variables of religious faith are accounted for by education differences and this can be classified as a moderate effect. A subsequent Tukey test for unequal values among the levels of education indicated a predominance of the level of high school education against those of lyceum and graduate $(\mathrm{t}=.42, p<.001$, and $\mathrm{t}=.48, p<.001$, respectively).

\subsection{Developmental changes in religious cognitive schemas over time}

Regarding developmental changes in religious cognitive schemas in relation to age, descriptive statistics (Table 1) presented the following data. Initially for ttt schema analysis showed a score dominance of age group 61 and over $(M=4.05, S D=.59)$. Analysis also showed that scores of the first three age groups $(13-24$ years $)$ presented a downward trend. On the contrary scores of 25 years of age group showed an upward trend.

For ftr schema analysis presented a score dominance of the age group of 41-60. In this schema scores showed a downward trend among ages of 13-18 years while scores of ages 19-60 presented an upward trend. Ages from 61 and above scores were found to decrease.

Finally, for xenos schema scores of age group 25-30 dominated, while trends for the specific schema did not present a clear course. Initially analysis showed a downward trend for ages 13-18, an upward trend for ages 19-30 and also an upward trend for ages 31 and over.

A multivariate analysis of variance (MANOVA) was performed to identify any group age differences on religious schemas. A one-way multivariate analysis of variance was performed with the use of three religious schemas (ttt, tfr, and xenos) as the dependent variables and Age Groups as the independent variable. The multivariate test revealed significant main effects for age (Wilks' lambda $=.684, F(276,781)=6.23, p<.001$, $n^{2}=.12$ ). The finding $\eta^{2}=.12$ indicates that $12 \%$ of the total variance in variables of religious schemas are accounted for by age differences and as such can be classified as a large effect. Subsequent univariate analysis showed that age diversified at all three religious schemas, $\operatorname{ttt}\left(F(6,285)=11.47, p<.001, n^{2}=.20\right), \mathrm{ftr}(F(6$, $\left.285)=2.53, p<.05, n^{2}=.05\right)$ and $\operatorname{xenos}\left(F(6,285)=3.79, p<.001, n^{2}=.08\right)$.

A subsequent Tukey test for unequal values for ttt schema among the groups of age, indicated a domination of age group 13-15 against age groups 16-18 and 19-24 ( $\mathrm{t}=.86, p<.001$, and $\mathrm{t}=.86, p<.001$, respectively). Age group 41-60 was dominant over age groups 16-18 and 19-24 $(\mathrm{t}=.63, p<.01$, and $\mathrm{t}=.64, p<.001$, respectively). Finally, age group 61 and over was dominant over age groups 16-18, 19-24, 25-30 and 41-60 (t = $1.22, p<.001, \mathrm{t}=1.23, p<.001, \mathrm{t}=.93, p<.05$, and $\mathrm{t}=.90, p<.05$, respectively).

Tukey test for ftr schema indicated a predominance of the age group 41-60 against age group 16-18 $(\mathrm{t}=.43$, $p<.05$ ), while for xenos schema a predominance was found of age group 13-15 against age groups 41-60 and 61 and over $(\mathrm{t}=.42, p<.05$, and $\mathrm{t}=.73, p<.01$, respectively), and age group 25-30 against age group 61 and over $(\mathrm{t}=.98, p<.05)$.

\subsection{Developmental changes on religious cognitive schemas in relation to education}

Descriptive statistics (Table 2) for ttt schema indicated a score domination for participants of high school education $(M=3.79, S D=.77)$. Scores for these schemas seem to follow a downward trend with the exception of participants on the last level of education whose scores show an upward trend. For ftr schema analysis showed a dominance of scores of participants of post graduate education $(M=4.31, S D=.63)$. Scores on four levels of education followed an upward trend. Finally, for xenos schema analysis presented a dominance of scores of participants on the post graduate level $(M=3.33, S D=.85)$, while the course of scores of the first levels presented a downward trend and of the last education level an upward trend.

A multivariate analysis of variance (MANOVA) was performed to identify any education levels related differences on religious schemas. A one-way multivariate analysis of variance was performed with the use of 
three religious schemas (ttt, tfr, and xenos) as the dependent variables and Education Levels as the independent variable. The multivariate test revealed significant main effects for education (Wilks' lambda $=.818, F(9,679)=$ $6.49, p<.001, n^{2}=.065$ ). The finding that $\eta^{2}=.065$ indicates that $6.5 \%$ of the total variance in variables of religious schemas are accounted for by age differences and this can be classified as a moderate effect. Subsequent univariate analysis showed that education diversified only on the religious schema $\operatorname{ttt}(F(3,285)=$ $\left.11.38, p<.001, n^{2}=.14\right)$.

A subsequent Tukey test for unequal values for ttt schema among education levels indicated a predominance of high school level against the levels of lyceum and graduate $(\mathrm{t}=.73, p<.001$, and $\mathrm{t}=.85, p<.001$, respectively). Analyses on ftr and xenos schemas did not reveal any dominance in scores of any level of education.

\subsection{Differences in religious faith and religious cognitive schemas in relation to gender}

Descriptive statistics (Table 3) regarding religious faith, showed that scores of females dominate over these of males ( $M=2.86, S D=.68$, and $M=2.70, S D=.66$, respectively). Analyses also revealed a dominance of the scores of females over scores of males on religious schemas $\mathrm{ttt}(M=3.30, S D=.90$, and $M=3.16, S D=.92$, respectively), $\operatorname{ftr}(M=4.18, S D=.54$, and $M=4.13, S D=.72$, respectively), and xenos $(M=3.18, S D=.77$, and $M=3.11, S D=.76$, respectively).

Table 3

Descriptive Statistics

\begin{tabular}{lccccccccc}
\hline \multirow{2}{*}{ Gender } & \multirow{2}{*}{$\mathrm{N}$} & \multicolumn{2}{c}{ Religious Faith } & \multicolumn{2}{c}{$\mathrm{ttt}$} & \multicolumn{2}{c}{ Religious schema } \\
\cline { 2 - 10 } & & $\mathrm{M}$ & $\mathrm{SD}$ & $\mathrm{M}$ & $\mathrm{SD}$ & $\mathrm{M}$ & $\mathrm{SD}$ & $\mathrm{M}$ & $\mathrm{SD}$ \\
\hline Men & 128 & 2.70 & .66 & 3.16 & .92 & 4.13 & .72 & 3.11 & .76 \\
Women & 157 & 2.86 & .68 & 3.30 & .90 & 4.18 & .54 & 3.18 & .77 \\
\hline Differences (Sig.) & \multicolumn{2}{c}{$F(1,279)=1.91, p<.05$} & $p>.05$ & & $p>.05$ & & $p>.05$ & \\
\hline
\end{tabular}

A univariate analysis of variance (ANOVA) was performed to identify any gender differences on religious faith. The analysis showed that religious faith differs in relation to gender $\left(F(1,279)=1.91, p<.05, n^{2}=.015\right)$. The finding $\eta^{2}=.015$ indicates that $1.5 \%$ of the total variance in variables of religious faith are accounted for by gender differences and as such can be classified as a small effect. A multivariate analysis of variance (MANOVA) was performed to identify any gender differences on religious schemas. A one-way multivariate analysis of variance was performed with the use of three religious schemas (ttt, tfr, and xenos) as the dependent variables and Gender as the independent variable. The multivariate test did not reveal significant main effects for gender (Wilks' lambda $\left.=.993, F(3,281)=.69, p=.558, n^{2}=.007\right)$.

\subsection{Relationship between religious schemas and religious faith}

Initially simple correlations between religious faith and religious schemas were examined. Results suggested significant associations between religious faith and the two schemas $\mathrm{ttt}$ and $\mathrm{ftr}(r=.84, p<.01$, and $r=.22, p$ $<.05$, respectively), while no significant association was found with the xenos schema. Interestingly, Religious Schemas demonstrated significant associations among them, the ttt schema with the ftr and xenos schema ( $r$ $=.26, p<.01$, and $r=.15, p<.05$, respectively $)$, the ftr schema and xenos $(r=.19, p<.05)$.

The present study explored whether religious faith could affect religious cognitive schemas. The predicting (independent) variable, i.e. religious faith was used in the regression analysis for each one of the three religious schemas (dependent variables). Results indicated a significant relation between religious faith and the two out of the three religious schemas, $\mathrm{ttt}\left(R=.837, R^{2}=.701\right), F(1,278)=652.58, p<.001$, accounting for the $70.1 \%$ of the variance, and $\mathrm{ftr}\left(R=.219, R^{2}=.048\right), F(1,278)=13.94, p<.001$, accounting for the $4.8 \%$ of the variance. These results did not show a significant relation among religious faith and xenos schema. The standardized beta 
Religiosity: Development of religious cognitive schemas and religious faith

coefficient (Table 4 ), revealed a positive effect for religious faith on ttt schema $(\beta=.837)$, and ftr schema $(\beta$ $=.219)$.

\section{Table 4}

Results of Standard Regression Analyses

\begin{tabular}{lccc}
\hline \multicolumn{1}{c}{ Variable } & B & SE & $\beta$ \\
\hline $\mathrm{ttt} \quad$ Religious faith & 1.13 & .044 & $.837^{*}$ \\
$\mathrm{ftr} \quad$ Religious faith & .203 & .054 & $.219^{*}$ \\
$\begin{array}{l}\text { xenos } \\
\text { Religious faith }\end{array}$ & .094 & .068 & $.082^{\mathrm{ns}}$ \\
\hline Note. ${ }^{*} p<.001{ }^{\mathrm{n} s}=$ no significant & & &
\end{tabular}

\section{Discussion}

The goals of the present study were to investigate developmental changes in religiosity by examining changes affecting the strength of religious faith and religious cognitive schemas in relation to age, education and gender. The present study also examined the relation among the two measures of religiosity, religious faith and religious schemas.

\subsection{Developmental changes of religiosity in relation to age}

Due to the fact that religion provides purpose and meaning in life, the present study hypothesized that religion is positively related to functioning in old age. The findings confirmed the above hypothesis showing initially the effect of age on the formation of religiosity (religious faith and religious schemas). The specific finding on the association between age and changes in modes of knowing that are conducive to spiritual development is supported by the findings of another study (Labouvie-Vief, DeVoe, \& Bulka, 1989). Following, and through the examination of religiosity through religious faith, the present finding revealed that the strength of religious faith is much more intense in late adults, old age (61 years and above) and adults contrary to teenagers. This finding enhances theories that state that spiritual development comes in the second half of adulthood (Jung, 1943, 1964; McFadden, 1996).

By examining changes found in the strength of religious faith through the years and based on the findings of the present study it is showed that these changes do not maintain a steady course. It was initially revealed that the course of religiosity in early adolescence (13 years) up to late adolescence ( 24 years) follows a downward trend while in ages 25-30 there is an upward trend which is followed by a steady period in early and middle adults (31-60 years). Finally, in old age religiosity shows an upward trend. This finding does not support the claim for a course of religiosity characterized by hierarchy and irreversibility (Fowler, 1981), but is in agreement to the controversy of assumptions regarding the structural wholeness, irreversibility and sequentiality of the stages (Streib 2001, 2010). Streib (2001, p. 150) suggested that there is no exclusive, one-directional linear trajectory in religious development. Baltes, Lindenberger, and Staudinger (2006) report that development is a sequence of predefined stages but it is conceptualized functionally and contextually as selective age-related change in adaptive capacity.

The present finding is not confirmed by findings of other studies (e.g., Benson, Scales, Sesma, \& Roehlkepartain, 2005) which found that almost two-thirds showed continuous levels of religious importance from the middle to high school years and the other third of the sample shows a discontinuity during this period. Smith and Denton (2005) supported that the setback of religiosity may begin after the age of 17. On the contrary, the findings of the present study on adults are in agreement to those of empirical studies which showed that religiosity is relatively stable throughout adulthood setting (e.g., Hout \& Greeley, 1987; Rossi, 2001; Wink \& Dillon 2008). A timeless study revealed a significant increase in spirituality from late middle (mid-50s/late-60s) 
to older adulthood (late 60s/mid-70s) (Wind \& Dillon, 2002). The variety presented among findings of all studies enhances the claim that age in cognitive-developmental theory is not a clear control factor of developmental changes (Rest, Deemer, Barnett, Spickelmeir, \& Volker, 1986).

Religious development in the present study was examined through the changes of religious schemas throughout the years by the use of Religious Schema Scale. Streib et al. (2010, p. 168) claimed that decline of absoluteness claim (ttt) and style developments towards tolerance (ftr), but especially towards the readiness for interreligious dialog (xenos) is a developmental progress. Findings enhance the above-mentioned claim since they presented a relative decrease of scores in tt followed by an increase of scores in ftr, as well as relatively high scores in xenos. Results also support the view that RSS is a suitable measurement for assessing religious development (Streib et al., 2010; Streib \& Klein, 2013).

The examination of the significance of differences among religiosity and various age groups revealed significant differences only on the way people think on religious exclusivity as this is expressed through the $t \mathrm{tt}$ schema and religious faith. On the contrary, thoughts where openness for fairness and tolerance stand in the foreground as well as the prevailing of interreligious dialog as these are expressed by ftr and xenos schemas, found not to vary significantly in the total of age groups. Similar, in part, seem to be the findings of a study showing a nonsignificant effect of age on religious schemas (Strieb et al., 2010). These findings enhance the claim that possibly children and adults may not totally vary in the way of thinking (Boyatzis, 2005).

\subsection{Religious changes in religiosity in relation to education}

Considering the fact that cognitive development is linked to spiritual growth the present study hypothesized that religious development should by affected by the level of educational background. The findings of the present study confirmed the above-mentioned hypothesis which is also supported by the study of Strieb et al. (2010), but this affect was found to be negative. In other words, it was found that religiosity was reduced by the increase of education level with the exception of the formation of thinking in ftr schema showing an upward trend. The same trend was observed on xenos, where changes in thinking were not significant. This finding is enhanced by the view of the proponents of post-formal stages of cognitive development that spirituality is the product of the maturity process occurring in the course of adult life (Jung, 1943, 1964; Wink \& Dillon, 2002). The above leads us to think that probably spiritual growth is not linked to educational development but is linked with the maturity processes and experiences (McFadden, 1996; Stokes, 1990). Based on the above-mentioned claim we may state that the present sample consisted of Orthodox Christians who live in a country (Greece) and are distinguished by experiences characterized by contradictions. First of all, by experiences those are characterized by a modernization as a result of a continuous accelerating economic and social reality during the final quarter of the twentieth century, and by experiences related to the quite powerful, historically and socially, nation-state and church relation. The present finding is possibly a result of such contradictory experiences.

\subsection{Religious changes in religiosity in relation to gender}

Another hypothesis of the present study was that religiosity should vary in relation to gender. The findings confirmed in part this hypothesis. Specifically, even though in both measurements was found that females show higher scores than males, differences were significant only on the strength of religious faith and not on the way of thinking as this is perceived by religious cognitive schemas. The first finding comes in agreement with these of other studies presenting differences on religiosity in relation to gender in adolescence (Smith \& Denton, 2005; Wallace et al., 2003) and adulthood (Batson et al., 1993; Donahue \& Benson, 1995; Henningsgaard \& Arnau, 2008). Nevertheless, the second finding regarding the way of thinking as this is presented following the assessment of religious styles/ schemas, appears to agree with some commentators in psychology of religion who state that differences among males and females on religious beliefs are important (Deconchy, 1973) as well as that the stereotype of females being more religious is misleading (Feltey \& Poloma, 1991). Streib et al. (2010) examined the religious development through the use of Religious Schema Scale and found that gender does not 
affect the formation of the religious faith. The above findings lead to the conclusion that gender is not a clear variable for the study of religiosity.

\subsection{Relation among religious faith and religious schemas}

Parallel to religious development the present study also examined the relation of the two scales of religious faith and religious schemas. Findings showed a high positive relationship among religious faith and the subscale truth of texts and teachings ( $t t t)$ and a moderate positive relation with the subscale fairness, tolerance \& rational choice ( $f r t$ ). Based on this finding we could claim that the subscale ttt measures data similar to religious faith and therefore can be used as a valid indicator of faith stages. This claim is not confirmed, since another study showed a medium negative relation among $t t t$ and religious faith (Strieb et al., 2010). At this point we should stress the difference in the sample used for each study, something that probably produces the differences in results. Nevertheless, the findings of the present study enhance the claim of researchers that RSS in total is not a measurement that accurately measures elements that are exclusively related to religious faith.

Additionally, the present study examined the level of correlation among the three subscales of RSS. Results showed a low to medium positive correlation among the three subscales, enhancing the claim that the three schemas of RSS are not independent structural units but part of a dynamic field with multiple interactions (Strieb et al., 2010). Moreover, the results of the positive correlation among ttt and xenos schemas leads to further examining the issue, since it comes in contrast to what a study of Strieb et al. (2010) proved.

\subsection{Limitations}

The current study showed a series of limitations. One limitation was the number of sample which is not representative of those of Orthodox Christian faith. A second limitation is derived again from the sample since it was comprised exclusively by Orthodox Christians and therefore results cannot be used for the total of religious faiths. A third limitation is the no representative number of sample in the category of post graduate. A final limitation is the absence of other similar studies in order to be able to compare results.

\section{Conclusions}

Based on the findings of the present study it can be initially concluded that the formation of religiosity is affected by various factors such are age, education and gender. It is also concluded that religious faith is significantly related to the religious-cognitive schema truth of texts and teachings (ttt) and a less significant relation to fairness, tolerance \& rational choice (frt). Finally, it is concluded that RSS is a measurement that can be used to measure developmental changes in religiosity.

\section{References}

Argyle, M., \& Beit-Hallahmi, B. (1975). The social psychology of religion. London: Routledge and Kegan Paul. Baltes, P. B., Lindenberger, U., \& Staudinger, U. M. (2006). Lifespan theory in developmental psychology. In R. Lerner \& W. Damon (Eds.), Handbook of child psychology: Theoretical models of human development (Vol. 1, pp. 569-664). Hoboken: Wiley.

Beit-Hallahmi, B., \& Argyle, M. (1997). The psychology of religious behavior, belief, and experience. New York: Routledge.

Benson, P. L., Scales, P. C. , Sesma, A. Jr., \& Roehlkepartain, E. C. ( 2005). Adolescent spirituality. In K. A. Moore \& L. H. Lippman (Eds.), What do children need to flourish? Conceptualizing and measuring indicators of positive development (pp. 25-40). New York: Springer. https://doi.org/10.1007/0-387-23823-9_3

Bourdieu, P. (1979). Distinction: A social critique of the judgment of taste. Cambridge: Harvard UP.

Boyatzis, C. J. (2005). Religious and spiritual development in childhood. In R. F. Paloutzian \& C. L. Park (Eds.), Handbook of the psychology of religion and spirituality (pp. 123-143). New York; London: The 
Guilford Press.

Day, J. M. (2010). Religion, spirituality, and positive psychology in adulthood: A developmental view. Journal of Adult Development, 17, 215-229. https://doi.org/10.1007/s10804-009-9086-7

Deconchy, J. P. (1973). Boys and girls choices for a religious group. In L. B. Browen (Ed.), Psychology and religion (pp. 284-300). Harmondsworth: Penguin.

Dianni, M., Proios, M., \& Kouthouris, C. (2014). Structure validity of Santa Clara Strength of Religious Faith questionnaire in Greek sample. Religions, 5(1), 157-164. https://doi.org/10.3390/rel5010157

Donahue, M. J., \& Benson, P. L. (1995). Religion and the well-being of adolescents. Journal of Social Issues, 51, 145-160. https://doi.org/10.1111/j.1540-4560.1995.tb01328.x

Feltey, K. M., \& Poloma, M. M. (1991). From sex differences to gender role beliefs: Exploring effects on six dimensions of religiosity. Sex Roles, 25, 181-193. https://doi.org/10.1007/BF00289853

Fetzer Institute/National Institute of Aging Working Group. (1999). Multidimensional measurement of religiousness/spirituality for use in health research: A report of the Fetzer institute/national institute on aging working group. Kalamazoo, MI: John E. Fetzer Institute.

Fowler, J. W. (1981). Stages of faith. New York: HarperCollins.

Fowler, J. W. (1987). Faith development and pastoral care. Philadelphia: Fortress Press.

Fowler, J. W. (1996). Pluralism and oneness in religious experience: William James, Faith-development theory, and clinical practice. In E. P. Shafranske (Ed.), Religion and the clinical practice of psychology (pp. 165-186). Washington, DC: American Psychological Association.

Fowler, J. W., \& Dell, M. L. (2005). Stages of faith from infancy through adolescence: Reflections on three decades of faith development theory. In P. E. King, L. Wagner, \& P. L. Benson (Eds.), The handbook of spiritual development in childhood and adolescence (pp. 34-45). Thousand Oaks, CA: Sage. https://doi.org/10.1037/10199-006

Gibson, T. S. (2004). Proposed levels of Christian maturity. Journal of Psychology and Theology, 32(4), 295-304.

Hackey, C. H., \& Sanders, G. S. (2003). Religiosity and mental health: A meta-analysis of recent studies. Journal for the Scientific Study of Religion, 42, 43-55. https://doi.org/10.1111/1468-5906.t01-1-00160

Henningsgaard, J. M., \& Arnau, R. C. (2008). Relationships between religiosity, spirituality, and personality: A multivariate analysis. Personality and Individual Differences, 45, 703-708. https://doi.org/10.1016/j.paid.2008.07.004

Hill, P. C., Pargament, K., Hood, R. W., McCullough, M. E., Swyers, J. P., Larson, D. B., et al. (2000). Conceptualizing religion and spirituality: Points of commonality, points of departure. Journal for the Theory of Social Behaviour, 30, 51-77. https://doi.org/10.1111/1468-5914.00119

Hout, M., \& Greeley, A. (1987). The center doesn't hold: Church attendance in the United States, 1940-1984. American Sociological Review, 52, 325-345. https://doi.org/10.2307/2095353

Jung, C. G. (1943). On the psychology of the unconscious. In H. Read, M. Fordham, \& G. Adler (Eds.), Jung: collected works (Vol. 7, pp. 76-83). Princeton, NJ: Princeton University Press.

Jung, C. G. (1964). Man and his symbols. New York: Laurel.

Keller, B., \& Streib, H. (2013). Faith development, religious styles and biographical narratives: methodological perspectives. Journal of Empirical Theology, 26, 1-21. https://doi.org/10.1163/15709256-12341255

King, J. E., \& Crowther, M. R. (2004). The measurement of religiosity and spirituality: Examples and issues from psychology. Journal of Organizational Change Management, 17(1), 83-101. https://doi.org/10.1108/09534810410511314

King, P. E., \& Roeser, R. W. (2009). Religion and spirituality in adolescent development. In R. M. Lerner \& L. Steinberg (Eds.), Handbook of adolescent psychology ( $3^{\text {rd }}$ ed., pp. 435-478). Hoboken, NJ: Wiley \& Sons. https://doi.org/10.1002/9780470479193.adlpsy001014

Labouvie-Vief, G., DeVoe, M., \& Bulka, D. (1989). Speaking about feelings: Conceptions of emotion across the life span. Psychology and Aging, 3, 425-437. https://doi.org/10.1037/0882-7974.4.4.425

McFadden, S. (1996). Religion and spirituality. In Encyclopedia of gerontology (Vol. 2, pp. 387-397). San Diego, CA: Academic Press. 
Religiosity: Development of religious cognitive schemas and religious faith

Paloutzian, R. F., \& Park, C. L (2005). Handbook of the psychology of religion and spirituality. New York: Guilford Press.

Pargament, K. (1999). The psychology of religion and spirituality? Yes and no. International Journal for the Psychology of Religion, 9, 3-16. https://doi.org/10.1207/s15327582ijpr0901_2

Peterman, A. H., Fitchett, G., Brady, M. J., Hernandez, L., \& Cella, D. (2002). Measuring spiritual well-being in people with cancer: The functional assessment of chronic illness therapy-spiritual well-being scale (FACIT-Sp). Annals of Behavioral Medicine, 24, 49-58. https://doi.org/10.1207/S15324796ABM2401_06

Plante, T. G., \& Boccaccini, M. T. (1997a). The Santa Clara Strength of Religious Faith questionnaire. Pastoral Psychology, 45(5), 375-387. https://doi.org/10.1007/BF02230993

Plante, T. G., \& Boccaccini, M. T. (1997b). Reliability and validity of the Santa Clara Strength of Religious Faith questionnaire. Pastoral Psychology, 45, 429-437. https://doi.org/10.1007/BF02310643

Proios, M. (2015). Structure validity of the Religious Schema Scale of Religious Faith Questionnaire in Greek sample. Journal of Social Science Studies, 2(1), 343-353. https://doi.org/10.5296/jsss.v2i1.6844

Rest, J., Deemer, O., Barnett, K., Spickelmeir, J., \& Volker, J. (1986). Life experiences and developmental pathways. In J. Rest (Ed.), Moral development, advances in research and theory (pp. 28-58). New York: Praeger.

Roof, W. C. (1999). Spiritual marketplace: Baby boomers and the remaking of American religion. Princeton, NJ: Princeton University Press.

Rossi, A. S. (2001). Caring and doing for others. Chicago: University of Chicago Press.

Sinnott, J. (1994). Development and yearning: Cognitive aspects of spiritual development. Journal of Adult Development, 1, 91-99. https://doi.org/10.1007/BF02259675

Smith, C., \& Denton, M. (2005). Soul searching: The religious and spiritual lives of American teenagers. New York: Oxford University Press. https://doi.org/10.1093/019518095X.001.0001

Stifoss-Hanssen, H. (1999). Religion and spirituality: What a European ear hears. International Journal for the Psychology of Religion, 9, 25-33. https://doi.org/10.1207/s15327582ijpr0901_4

Stokes, K. (1990). Faith development in the adult life cycle. Journal of Religious Gerontology, 7, $167-184$. https://doi.org/10.1300/J078V07N01_13

Streib, H. (2001). Faith Development Theory revisited: The religious styles perspective. The International Journal for the Psychology of Religion, 11, 143-158. https://doi.org/10.1207/S15327582IJPR1103_02

Streib, H. (2010). Conceptualizing and measuring religious development in terms of religious styles and schemata: New considerations. Paper for the Psychologie du développement religieux: questions classiques et perspectives contemporairnes, Lausanne. Retrieved from http://pub.uni-bielefeld.de/pub?func=drec\&id=2276876

Streib, H., Hood, R. W., \& Klein, C. (2010). The religious schema scale: Construction and initial validation of a qualitative measure for religious styles. The International Journal for the Psychology of Religion, 20, 151-172. https://doi.org/10.1080/10508619.2010.481223

Wallace, J. M., Forman, T. A., Caldwell, C. H., \& Willis, D. S. (2003). Religion and American youth: Recent patterns, historical trends and sociodemographic correlates. Youth and Society, 35, 98-125. https://doi.org/10.1177/0044118X03254564

Winer, F. (1989). The elderly jock and how he got that way. In J. H. Goldstein (Ed.), Sports, games, and play: Social and psychological viewpoints (2nd ed., pp. 147-173). Hillsdale, NJ: Erlbaum.

Wink, P., \& Dillon, M. (2002). Spiritual development across the adult life course: Findings from a longitudinal study. Journal of Adult Development, 9(1), 79-94. https://doi.org/10.1023/A:1013833419122

Wink, P., \& Dillon, M. (2008). Regiligiousness, spirituality, and psychosocial functioning in late adulthood: Findings from a longitudinal study. Psychology of Religion and Spirituality, 8(1), 102-115. https://doi.org/10.1037/1941-1022.S.1.102

Zinnbauer, B., Pargament, K. I., Cowell, B., et al. (1997). Religion and spirituality: Unfuzzying the fuzzy. Journal for the Scientific Study of Religion, 36, 549-564. https://doi.org/10.2307/1387689 
Proios, M., Dianni, M., Samara, E., \& Syropoulos, D. 